\title{
PENGARUH PENGGUNAAN PENILAIAN BERDASARKAN FORTOPOLIO TERHADAP PRESTASI BELAJAR FISIKA SISWA
}

Oleh: I Made Astra *)

\section{Abstrak}

Dengan diterapkannya di semua tingkat sekolah sekarang yaitu kurikulum tingkat satuan pendidikan, maka guru diharapkan bisa menerapkan kurikulum tersebut dengan baik. Demikian pula dalam hal penilaian guru dituntut mencari sistem penilaian yang tepat, supaya tidak merugikan semua siswa. Salah satu sistem penilaian yang perlu dicoba adalah penilaian berdasarkan fortopolio, yaitu penilaian yang menilai semua hasil kerja siswa. Atas dasar itu telah diteliti pengaruh penggunaan penilaian berdasarkan fortopolio terhadap hasil belajar fisika siswa. Penelitian ini dilakukan di SMA YP UNJ terhadap siswa kelas XI. Penelitian ini menggunakan metode quasi eksperimen. Dari hasil penelitian diperoleh hasil yaitu ada peningkatan prestasi belajar fisika siswa dengan menggunakan penilaian berdasarkan fortopolio. Untuk itu para guru di sekolah bisa menggunakan cara penilaian tersebut terhadap anak didiknya.

\section{PENDAHULUAN}

\section{A. Latar Belakang Masalah}

Adanya perkembangan ilmu pengetahuan dan teknologi yang sangat pesat dewasa ini sangat berpengaruh terhadap kehidupan masyarakat. Masyarakat cenderung mengalami perubahan pola pikir dan gaya hidup, bahkan kehidupan masyarakat kini tidak lagi dapat dipisahkan dari kedua aspek tersebut.

Kalangan masyarakat yang sedikit memiliki ilmu pengetahuan dan kurang menguasai teknologi akan jauh tertinggal oleh masyarakat yang kaya akan ilmu pengetahuan dan mahir dalam hal teknologi. Sehingga untuk mengurangi jarak ketertinggalan, setiap orang harus menggali ilmu pengetahuan dan teknologi sedalam mungkin yakni dengan cara belajar.

Modal dasar dan kunci keberhasilan pembangunan nasional adalah sumber daya manusia yang berkualitas. Hal ini merupakan tantangan bagi sekolah sebagai pencetak generasi penerus bangsa untuk menghasilkan lulusan yang berkualitas,yakni dengan cara meningkatkan mutu pendidikan.

Banyak faktor yang mempengaruhi mutu suatu pendidikan. Salah satu faktor yang perlu mendapatkan perhatian lebih adalah faktor kompetensi guru. Pembaruan dibidang pendidikan tidak harus disertai dengan pemakaian alat yang serba modern, tetapi perlu ditekankan pada pentingnya pengembangan cara-cara baru dalam mencapai efektifitas belajar, termasuk

*) Dr. I Made Astra, M.Si adalah dosen pada jurusan fisika MIPA UNJ. 
didalamnya adalah cara-cara atau teknik penilaian.

Pemerintah mengeluarkan kebijakan untuk menggunakan Kurikulum Berbasis Kompetensi (KBK) atau nama lainnya adalah kurikulum 2004. Kebijakan ini didasarkan pada Peraturan Pemerintah Nomor 25 tahun 2000 dan diperkuat dengan ditetapkannya "Undang-Undang Sisdiknas (Sistem Pendidikan Nasional) nomor 20 tahun 2003 bab IX pasal 35 ayat (1) bahwa standar pendidikan terdiri atas isi, proses, kompetensi lulusan, tenaga kependidikan, sarana dan prasarana, pengelolaan, pembiayaan, dan penilaian yang harus ditingkatkan secara berencana dan berkala." (Yamin, 2004) Oleh karena itu, dari tingkat Sekolah Dasar hingga Sekolah Menengah Atas mulai menerapkan KBK.

Penyempurnaan kurikulum dilaksanakan sebagai salah satu upaya peningkatan mutu pendidikan. Penyempurnaan dilakukan karena hasil penilaian pelaksanaan kurikulum 1994 menunjukkan bahwa penilaian yang dilakukan di kelas kurang mampu memperlihatkan tuntutan hasil belajar siswa, yaitu:

1. Mengungkapkan pemahamannya secara lisan dan tertulis

2. Mengekspresikan gagasan, khususnya dalam bentuk gambar, grafik, diagram, atau symbol lainnya

3. Mengembangkan keterampilan fungsional sebagai hasil interaksi dengan lingkungan fisik, sosial, dan budaya

4. Menggunakan lingkungan (fisik, sosial, dan budaya) sebagai sumber dan media belajar

5. Membuat laporan penelitian dan membuat sinopsis

6. Mengembangkan kemampuan berekspresi dan mengaktualisasi diri. (Asworo, 2005)

Kelemahan-kelemahan tersebut diatas harus diatasi dengan penilaian atau penilaian yang bersifat menyeluruh pada ketiga aspek yaitu: kognitif, afektif dan psikomotorik, serta penilaian berkesinambungan yang dilakukan selama proses pembelajaran.

Model penilaian yang dikembangkan saat ini adalah model penilaian berbasis kelas. Penilaian berbasis kelas adalah proses pengumpulan dan penggunaan informasi oleh guru untuk pemberian nilai terhadap hasil belajar siswa berdasarkan tahapan kemajuan belajarnya, sehingga didapatkan potret/profil kemampuan siswa sesuai dengan daftar kompetensi yang ditetapkan dalam kurikulum.(Asworo, 2005) Penilaian ini dilakukan oleh guru untuk mengetahui kemajuan siswa, hasil belajar siswa, mendiagnosa kesulitan belajar, dan menentukan kenaikan kelas. Penilaian berbasis kelas dilakukan antara lain melalui Portfolios (Kumpulan Kerja Siswa), Performances (Unjuk Kerja), dan Paper and Pencils (tes tulis). (Supriyati, 2004)

Peneliti mencoba mengangkat satu hal penting dari penyebab utama ketidak berhasilan penilaian dalam pendidikan, yaitu orientasi pendidikan yang hanya terfokus pada pemberian materi saja yang tujuannya untuk mencerdaskan siswa secara kognitif. Sementara pendidikan tentang sikap dan nilai-nilai yang sangat penting bagi kehidupan siswa cenderung terlupakan karena ukuran nilai dan sikap tidak dapat diwakili oleh suatu skor (angka).

Bersamaan dengan diujikannya KBK, kebutuhan akan penilaian yang bersifat komprehensif dirasa makin mendesak. Banyak hal yang harus diperhatikan dalam memutuskan hasil akhir proses belajar siswa, dan hal ini tidak terwakili oleh model penilaian yang lama.

Untuk menjawab kebutuhan akan sebuah penilaian yang komprehensif, penilaian atau penilaian secara portofolio mulai menjadi perhatian. Model penilaian ini merangkum kegiatan siswa baik secara akademik maupun non akademik sebagai pertimbangan penilaian hasil belajar siswa. Tidak hanya itu kondisi dan situasi saat proses belajar berlangsung pun ikut 
dijadikan bahan pertimbangan.

Model penilaian yang terbilang baru ini dapat menjawab kebutuhan untuk melakukan penilaian yang lengkap mengenai kemajuan belajar siswa yang meliputi aspek kognitif, afektif dan psikomotorik. Perkembangan kemampuan siswa dalam pembelajaran fisika pun dapat terpantau dengan menggunakan model penilaian ini.

Ternyata pada prakteknya, saat pelaksanaan penelitian sekolah sudah tidak menggunakan KBK lagi, tetapi menggunakan Kurikulum Tingkat Satuan Pendidikan (KTSP). Akan tetapi untuk model penilaian portofolio sangat cocok digunakan karena penilaian yang digunakan pada KTSP dilakukan terhadap pengusaan siswa tiap indikator

\section{B. Identifikasi Masalah}

Berdasarkan uraian latar belakang masalah diatas, maka dapat diidentifikasikan beberapa masalah sebagai berikut:

1. Apakah portofolio dapat menilai aspek afektif dan psikomotorik siswa?

2. Apakah portofolio dapat menilai keterampilan siswa dalam melakukan penelitian ?

3. Apakah portofolio dapat menilai keterampilan siswa dalam membuat sinopsis atau laporan hasil penelitian?

4. Kumpulan kerja (portofolio) apa sajakah yang dapat dilakukan siswa SMA?

5. Apakah pengaruh penggunaan penilaian secara portofolio(Kumpulan Kerja Siswa) terhadap hasil belajar fisika siswa di SMA?

\section{Pembatasan Masalah}

Berdasarkan identifikasi masalah diatas, peneliti membatasi masalah pada pengaruh penggunaan penilaian secara portofolio (kumpulan kerja siswa) terhadap hasil belajar fisika siswa SMA kelas sebelas (XI).

\section{Perumusan Masalah}

Dari masalah yang ada dapat dirumuskan sebuah masalah yaitu: "Apakah pengaruh penggunaan penilaian secara portofolio terhadap hasil belajar fisika siswa SMA?"

\section{E. Tujuan Penelitian}

Adapun penelitian ini dilakukan dengan tujuan untuk mengetahui pengaruh penggunaan penilaian secara portofolio dalam proses pembelajaran fisika terhadap hasil belajar siswa SMA, dimana hasil belajar yang dinilai meliputi 3 ranah yaitu kognitif, afektif dan psikomotorik.

\section{F. Manfaat Penelitian}

Hasil penelitian ini diharapkan dapat bermanfaat bagi guru khususnya fisika, siswa dan mahasiswa fisika sebagai calon guru. Bagi guru mata pelajaran fisika, agar dapat memberikan masukan tentang penggunaan portofolio dalam melakukan penilaian sehingga diperoleh penilaian yang bersifat menyeluruh baik aspek kognitif, afektif maupun psikomotorik.

Manfaat bagi siswa, supaya siswa lebih terampil dalam melakukan penelitian dan juga cerdas dalam mengolah hasil penelitian/percobaan tersebut dalam bentuk laporan, siswa lebih variatif dalam menungkan ide/pemikirannya dalam bentuk makalah.

Kegunaan bagi mahasiswa sebagai calon guru, agar dapat memperkaya pengetahuan mereka tentang portofolio beserta teknik penilaiannya, yang dapat mereka terapkan dalam proses pembelajaran .

\section{LANDASAN TEORI DAN KERANGKA BERPIKIR}

\section{A. Landasan Teori}

1. Pengertian Hasil Belajar Fisika Beberapa aliran yang mengemukakan pandangan tentang belajar yang dikutip dalam buku Ali Imron, diantaranya yaitu: 
a. Pandangan psikologi behavioristik, belajar adalah suatu kontrol instrumental yang berasal dari lingkungan

b. Pandangan kognitif, belajar adalah suatu usaha untuk mengerti tentang sesuatu

c. Pandangan humanistik, belajar dilakukan dengan cara memberikan kebebasan yang sebesar-besarnya kepada individu

d. Pandangan Gestalt, belajar terdiri dari hubungan stimulus respons yang sederhana tanpa adanya pengulangan ide/proses berpikir

(Imron, 1996)

Pengertian belajar dari beberapa ahli yang dikutip oleh Nana Sudjana:

a. Mouly mengatakan bahwa belajar adalah proses perubahan tingkah laku seseorang berkat adanya pengalaman

b. Kimble dan Garmezi mengatakan bahwa belajar adalah perubahan tingkah laku yang relatif permanen terjadi sebagai hasil dari pengalaman

c. Gerry dan Kingsley menyatakan belajar adalah proses perubahan tingkah laku yang meliputi: perubahan keterampilan, kebiasaan, sikap, pengetahuan, pengalaman dan apresiasi berkat adanya pengalaman dalam proses belajar yang berasal dari interaksi individu dengan lingkungan

(Sudjana, 1997)

Dari beberapa pengertian belajar diatas dapat diambil kesimpulan bahwa belajar adalah suatu proses perubahan tingkah laku seseorang, yang dilakukan secara sadar akibat adanya pengalaman dan latihan. Perubahan tersebut bersifat permanen yang meliputi perubahan pengetahuan, keterampilan dan sikap.

Menurut Nyoman Kertiasa, Fisika merupakan bagian dari ilmu pengetahuan alam yang mempelajari sifat-sifat gejala alam yang dinyatakan dalam zat dan energi (Kertiasa, 1997). Sedangkan menurut Herbert Druxes, dalam buku yang telah diterjemahkan oleh Soepomo menyatakan bahwa fisika merupakan ilmu pengetahuan yang berusaha menguraikan serta menjelaskan hukum-hukum alam dan kejadiankejadian alam dengan gambaran menurut pemikiran manusia (Druxes, 1983). Fisika diawali dengan mengamati gejala alam yang harus disertai data kuantitatif dari hasil pengukuran, bahkan menurut seorang fisikawan bernama Lord Kelvin berkata: " bila kita dapat mengukur apa yang sedang kita bicarakan dan menyatakannya dengan angka-angka berarti kita mengetahui apa yang kita bicarakan." (Kanginan, 2002).

Jadi pada dasarnya fisika adalah ilmu pengetahuan dasar dan murni seperti matematika, kimia, biologi yang menjelaskan tentang hukum-hukum alam beserta gejala-gejalanya.

Menurut Nana Sudjana, hasil belajar diartikan sebagai kemampuankemampuan yang dimiliki siswa setelah menerima pengalaman belajar. Pengalaman belajar tersebut diperoleh siswa dalam proses pembelajaran. Pada proses pembelajaran itu terjadi interaksi antara siswa dengan lingkungannya sehingga terjadi pengalaman belajar pada diri siswa (Sudjana, 1992).

Dalam sistem pendidikan nasional menggunakan klasifikasi hasil belajar dari Benyamin Bloom seperti yang dikutip oleh Nana Sudjana yang membagi menjadi 3 ranah yaitu:

a. Kognitif: pengetahuan atau ingatan, pemahaman, aplikasi, analisis, sintesis dan penilaian

b. Afektif : penerimaan, jawaban atau reaksi, penilaian, organisasi dan internalisasi 
c. Psikomotorik: gerakan refleks, ketrampilan gerakan dasar, kemampuan perceptual, keharmonisan atau ketepatan, gerakan ketrampilan kompleks, gerakan ekspresif dan interpretatif (Sudjana, 2001).

Jadi hasil belajar merupakan tingkah laku akhir (terminal) dari kegiatan belajar siswa yang dapat diamati, sehingga hasil belajar merupakan pencerminan proses pengajaran yang telah berlangsung.

Dari definisi-definisi tersebut di atas dapat diambil kesimpulan bahwa pengertian dari hasil belajar fisika adalah tingkat penguasaan yang dicapai siswa dalam mengikuti proses belajar mengajar mata pelajaran fisika sesuai dengan tujuan yang ditetapkan dengan menghasilkan kemampuan dalam 3 ranah yaitu kognitif, afektif dan psikomotorik.

Hasil belajar yang dimaksud dalam penelitian ini adalah nilai yang diperoleh siswa dalam mata pelajaran fisika secara kognitif saja, sedangkan untuk ranah afektif dan psikomotorik dinilai pada saat proses belajar mengajar karena masuk ke dalam rangkaian penilaian portofolio.

\section{Pengertian Penilaian}

Salah satu tugas guru adalah memonitor, mengpenilaian dan menunjukkan apakah pengetahuan siswa berlaku untuk menghadapi persoalan baru yang berkaitan. Suparno, 1997). Penilaian adalah suatu proses untuk menentukan nilai dari suatu proses pembelajaran yang telah dilakukan untuk mengetahui apakah tujuan pembelajaran telah tercapai.(Miarso, 1994).

Penilaian atau penilaian merupakan salah satu kegiatan yang sangat penting dalam proses pembelajaran, karena dengan adanya kegiatan penilaian akan diketahui apakah tujuan pembelajaran yang sudah ditetapkan telah tercapai. Selain itu penilaian juga dapat mengukur tingkat keberhasilan guru dalam mendidik dan mengajar, serta dapat mengukur keberhasilan siswa dalam belajar. Penilaian adalah suatu keputusan tentang nilai yang dipengaruhi oleh hasil pengukuran. Sedangkan pengukuran adalah proses pengumpulan data melalui pengamatan empiris. Untuk menaksir prestasi siswa, guru melakukan pengukuran dengan membaca apa yang telah dilakukan siswa, mengamati kinerja mereka, mendengarkan apa yang mereka katakan dan pada umumnya menggunakan indra mereka dalam bentuk mengumpulkan informasi yang relevan dengan tujuan yang telah dinyatakan. (Cangelosi, 1995).

Jadi penilaian pada dasarnya berhubungan dengan setiap bagian dari proses pembelajaran, bukan hanya keberhasilan belajar saja, tetapi mencakup semua proses pembelajaran, dan kegiatannya tidak terbatas pada karakteristik siswa saja, tetapi juga mencakup karakteristik metode mengajar, kurikulum, fasilitas, dan administrasi sekolah.

Tes adalah pengukuran terencana yang dipakai para guru untuk mencoba menciptakan kesempatan bagi siswanya untuk memperlihatkan prestasi mereka dalam kaitannya dengan tujuan yang telah ditetapkan. (Cangelosi, 1995)

Dalam mendapat pengukuran kompetensi dasar siswa, kita perlu membuat alat penjaringan informasi berupa tagihan-tagihan. Tagihantagihan ini dirancang sedemikian rupa dan bervariasi,sehingga merupakan sistem dalam pengujian kompetensi dasar siswa, yang berkaitan dengan kognitif ataupun psikomotorik, antara lain: 
a. Pertanyaan lisan

Materi yang ditanyakan berupa pemahaman konsep, prinsip, atau teorema. Pertanyaan ini kita lemparkan kepada siswa, kemudian mereka diberi kesempatan untuk berpikir, lalu kita pilih satu siswa untuk menjawab. Dalam menjawab siswa diberi kebebasan untuk mengemukakan gagasannya. Selanjutnya dilempar ke siswa lain untuk mengklarifikasi jawaban tersebut. Setelah itu guru menyimpulkan jawaban yang benar.Pertanyaan ini dapat dilakukan diawal maupun akhir pelajaran.

b. Kuis

Pertanyaan yang diajukan kepada siswa dalam waktu yang terbatas, kurang lebih 15 menit. Pertanyaannya dalam bentuk option atau jawaban singkat. Kuis dilakukan untuk mendapatkan gambaran tentang materi sebelumnya yang telah diajarkan ke siswa. Biasanya dilakukan diawal pelajaran. Jika masih ada siswa yang tidak menguasai materi tersebut, maka sebaiknya dijelaskan kembali secara singkat.

c. Ulangan Harian

Ulangan harian dapat dilakukan secara periodic, setiap materi pokok yang diajarkan selesai. Guru dapat membuat soal dalam bentuk objektif maupun non objektif. Tingkat berpikir yang terlibat sebaiknya mencakup pemahaman, aplikasi dan analisis.

d. Tugas Individu

Tugas individu dapat diberikan setiap minggu dengan bentuk tugas/soal uraian objektif maupun non objektif. Tingkat berpikir yang terlibat sebaiknya aplikasi, analisis, bila mungkin sampai sintesis dan penilaian.

e. Tugas Kelompok

Tugas kelompok digunakan untuk menilai kemampuan kerja kelompok. Bentuk soal yang digunakan adalah uraian dengan tingkat berpikir yang tinggi yaitu aplikasi sampai penilaian. Siswa dianjurkan untuk mencari data di lapangan atau melakukan pengamatan terhadap suatu fenomena, atau membuat suatu kegiatan terencana dan dilakukan secara berkelompok, tugas ini menekankan pada penilaian psikomotor.

f. Ulangan Semester

Adalah ujian yang dilakukan pada akhir semester, dengan bentuk soal ujian pilihan ganda atau uraian, campuran pilihan ganda dan uraian, atau uraian semua. Materi yang diujikan berdasarkan kisi-kisi soal. Tingkat berpikir yang terlibat dari pemahaman hingga penilaian.

g. Ulangan kenaikan kelas

Ujian kenaikan kelas sama dengan ujian semester, hanya cakupan materinya yang lebih banyak, karena materi yang diujikan dalam satu tahun pelajaran. Akan tetapi materinya harus mengacu pada materi yang essensial, berkelanjutan,dan memiliki nilai aplikatif.

h. Laporan Praktikum

Mata pelajaran yang dapat dilakukan dalam bentuk praktikun di laboratorium adalah mata pelajaran tertentu seperti fisika, kimia dan biologi.

i. Responsi atau ujian praktik

Responsi yang dilakukan adalah mata pelajaran yang berkaitan dendan praktik dan laboratorium. Responsi digunakan untuk mengetahui penguasaan akhir siswa terhadap materi pelajaran pada tingkat kognitif dan psikomotorik.

j. Ujian Akhir

Bentuk soal yang digunakan hampir sama pada ujian semester, kenaikan kelas, akan tetapi cakupan materi yang diuji lebih luas, karena menguji kemampuan siswa dari kelas 
awal sampai akhir. Pemilihan materinya harus essensial, mewakili seluruh standar kompetensi yang ada.

Tagihan-tagihan yang dilakukan dalam sistem pengujian berbasis kompetensi dasar, meliputi tingkat berpikir yang berkaitan dengan pengetahuan deklaratif dan pengetahuan prosedural. Deklaratif berisi tentang konsep, fakta,dan prinsip. Sedangkan prosedural meliputi proses, strategi, aplikasi,dan keterampilan. (Yamin, 2004)

3. Pengertian Portofolio

Menurut Budimansyah, Portofolio sebenarnya dapat diartikan sebagai suatu wujud benda fisik, sebagai suatu proses social pedagogis,maupun sebagai adjektif. Sebagai suatu wujud benda fisik portofolio itu adalah bundel, yakni kumpulan atau dokumentasi hasil pekerjaan peserta didik yang disimpan pada suatu bundel. Misalnya hasil test awal(pre test), tugas-tugas, hasil test akhir(post test), dan sebagainya (Budimansyah, 2003).

Sebagai suatu proses sosial pedagogis, portofolio adalah collection of learning experience yang terdapat didalam pikiran peserta didik baik yang berwujud pengetahuan (kognitif), ketrampilan (psikomotorik), maupun nilai dan sikap(afektif). Adapun sebagai suatu adjektif portofolio sering kali dihubungkan dengan konsep lain, misalnya dengan konsep pembelajaran dan penilaian. Jika dihubungkan dengan konsep pembelajaran maka dikenal istilah pembelajaran berbasis portofolio (portfolio based learning), sedangkan jika disandingkan dengan konsep penilaian maka dikenal istilah penilaian berbasis portofolio (portfolio based assessment).

Batasan portofolio oleh beberapa ahli menurut data yang ditulis oleh Elin
Rusoni, 2001) antara lain sebagai berikut:

a. Paulson, mendefinisikan portofolio sebagai kumpulan pekerjaan siswa yang menunjukkan usaha, perkembangan dan kecakapan mereka dalam satu bidang atau lebih. Kumpulan ini harus mencakup partisipasi siswa dalam seleksi isi, kriteria seleksi, kriteria penilaian dan bukti refleksi diri (Paulson, 1991).

b. Menurut Gronlund, portofolio mencakup berbagai contoh pekerjaan siswa yang tergantung pada keluasan tujuan. Apa yang harus tersurat, tergantung pada subjek dan tujuan penggunaan portofolio (Gronlund, 1998). Contoh pekerjaan siswa ini memberikan dasar bagi pertimbangan kemajuan belajarnya dan dapat dikomunikasikan kepada siswa, orang tua serta pihak lain yang tertarik dan berkepentingan.

Portofolio dapat digunakan untuk $\mathrm{m}$ e $\mathrm{nd} \mathrm{o} \mathrm{k} \mathrm{u} \mathrm{m} \mathrm{e} \mathrm{n} \mathrm{t}$ a s i k a perkembangan siswa. Karena menyadari proses belajar sangat penting untuk keberhasilan hidup, portofolio dapat digunakan oleh siswa untuk melihat kemajuan mereka sendiri terutama dalam hal perkembangan, sikap keterampilan dan ekspresinya terhadap sesuatu.

Secara umum, portofolio merupakan kumpulan hasil karya siswa atau catatan mengenai siswa yang didokumentasikan secara baik dan teratur. Portofolio dapat berbentuk tugas-tugas yang dikerjakan siswa, jawaban siswa atas pertanyaan guru, catatan hasil observasi guru, catatan hasil wawancara guru dengan siswa, laporan kegiatan siswa dan karangan atau jurnal yang dibuat siswa. 
Menurut Sumarna Surapranata dan Muhammad Hatta, penilaian portofolio merupakan penilaian berbasis kelas terhadap sekumpulan karya peserta didik yang tersusun secara sistematis dan terorganisasi yang diambil selama proses pembelajaran dalam kurun waktu tertentu, digunakan oleh guru dan peserta didik untuk memantau perkembangan pengetahuan, keterampilan, dan sikap peserta didik dalam mata pelajaran tertentu (Surapranata dan Hatta, 2006.

Mengingat begitu beragamnya jenis portofolio, guru dapat mengumpulkannya melalui beberapa cara. Cara yang akan dipakai disesuaikan dengan tujuan yang hendak dicapai, tingkatan siswa dan jenis kegiatan yang dilakukan.

\section{Model Portofolio}

Pada penelitian ini akan digunakan model penilaian portofolio sebagai berikut:

Tabel 1. Model penilaian portofolio

\begin{tabular}{|c|c|c|c|c|c|c|c|c|c|c|}
\hline Kompetensi Dasar & \multicolumn{10}{|c|}{$\begin{array}{l}\text { Nama peserta didik: } \\
\text { Tanggal: }\end{array}$} \\
\hline Indikator & \multicolumn{10}{|c|}{ PENILAIAN } \\
\hline 10 & 1 & 2 & 3 & 4 & 5 & 6 & 7 & 8 & 9 & 10 \\
\hline Dicapai melalui: & \multirow{5}{*}{\multicolumn{10}{|c|}{ Komentar guru: }} \\
\hline - $\quad$ Pertolongan guru & & & & & & & & & & \\
\hline - Seluruh kelas & & & & & & & & & & \\
\hline - Kelompok kecil & & & & & & & & & & \\
\hline - Sendiri & & & & & & & & & & \\
\hline \multicolumn{11}{|l|}{ Komentar orangtua: } \\
\hline
\end{tabular}

Bahan-bahan portofolio:

1. Penghargaan tertulis, misalnya sertifikat mengikuti lomba fisika

2. Penghargaan lisan, guru mencatat penghargaan lisan yang diberikan kepada peserta didik dalam kurun waktu tertentu

3. Hasil kerja biasa dan hasil pelaksanaan tugas-tugas oleh peserta didik, misalnya buku tugas, buku PR, klipping, foto atau gambar

4. Daftar ringkasan hasil pekerjaan, berupa buku catatan peserta didik

5. Catatan sebagai peserta dalam suatu kelompok

6. Contoh terbaik hasil pekerjaan, menurut pendapat guru dan peserta didik

7. Catatan dari pihak lain yang relevan, antara lain dari teman atau orang tua

8. Hasil rekapitulasi daftar kehadiran

9. Hasil ulangan harian atau semester

10. Prosentase dari tugas-tugas yang selesai dikerjakan

11. Catatan tentang peringatan yang diberikan guru jika peserta didik melakukan kesalahan

12. Audio Visual (Surapranata dan Hatta, 2006)

\section{Manfaat Portofolio}

Penilaian portofolio dapat digunakan untuk berbagai keperluan, misalnya seperti yang dikemukakan oleh Berenson dan Certer seperti yang ditulis oleh Elin Rusoni berikut ini:

1) Mendokumentasikan kemajuan siswa selama kurun waktu tertentu

2) Mengetahui bagian - bagian yang perlu diperbaiki

3) Membangkitkan kepercayaan diri dan motivasi untuk belajar

4) Mendorong tanggungjawab siswa untuk belajar (Rusoni , 2001).

Sedangkan menurut Gronlund (1998), portofolio memiliki beberapa keuntungan, antara lain sebagai berikut.

1) Kemajuan belajar siswa dapat terlihat dengan jelas

2) Penekanan pada hasil pekerjaan terbaik siswa memberikan pengaruh positif dalam belajar.

3) Membandingkan pekerjaan sekarang dengan yang lalu memberikan motivasi yang lebih besar dari pada membandingkan dengan milik orang lain 
4) Keterampilan asesmen sendiri dikembangkan mengarah pada seleksi contoh pekerjaan dan menentukan pilihan terbaik

5) Memberikan kesempatan siswa bekerja sesuai dengan perbedaan individu (misalnya siswa menulis sesuai dengan tingkat level mereka tetapi sama-sama menuju tujuan umum)

6) Dapat menjadi alat komunikasi yang jelas tentang kemajuan belajar siswa bagi siswa itu sendiri, orang tua, dan lainnya.

\section{B. Kerangka Berpikir}

Pada proses pembelajaran fisika di lapangan yang dinilai oleh guru pada umumnya hanya hasil belajar siswa secara kognitif saja. Orientasi pendidikan hanya terfokus pada pemberian materi saja, sementara pendidikan tentang nilai dan sikap terkesan diabaikan. Akibatnya siswa kurang memiliki keterampilan motorik dan sikap ilmiah. Padahal ketiga ranah tersebut harus dapat dicapai secara seimbang dalam proses pembelajaran.

Kelemahan-kelemahan pada proses penilaian hasil belajar siswa pada kurikulum 1994, menuntut adanya sebuah penyempurnaan. Solusi yang dianggap tepat adalah dengan digunakannya proses penilaian berbasis kelas yang bersifat menyeluruh pada ketiga aspek yaitu kognitif, afektik dan psikomotorik. Penilaian dilakukan guru untuk mengetahui kemajuan siswa, hasil belajar siswa, mendiagnosa kesulitan belajar, dan menentukan kenaikan kelas.

Salah satu bentuk penilaian berbasis kelas adalah penilaian portofolio. Penilaian ini merupakan penilaian terhadap sekumpulan karya peserta didik yang disusun secara sistematis yang diambil selama proses pembelajaran. Bentuk penilaian portofolio dilakukan pada setiap indikator pencapaian hasil belajar sesuai dengan kompetensi dasar yang hendak dicapai.
Jadi penggunaan penilaian secara portofolio dalam proses pembelajaran fisika diharapkan berpengaruh positif terhadap pencapaian hasil belajar siswa secara kognitif, afektif dan psikomotorik.

\section{Perumusan Hipotesis Penelitian}

Berdasarkan deskripsi teoritis dan kerangka berpikir, maka dapat dirumuskan hipotesis penelitian sebagai berikut: Ada pengaruh yang signifikan antara penggunaan penilaian secara portofolio terhadap hasil belajar fisika siswa.

\section{METODOLOGI PENELITIAN}

\section{A. Tujuan Operasional Penelitian}

Tujuan operasional penelitian yang hendak dicapai adalah untuk mengetahui pengaruh penggunaan penilaian portofolio dalam pembelajaran fisika terhadap hasil belajar siswa, yaitu dengan menganalisis secara empirik perbedaan hasil belajar siswa yang belajar dengan menggunakan portofolio dengan siswa yang belajar tanpa menggunakan portofolio.

\section{B. Tempat dan Waktu Penelitian}

Penelitian ini akan dilaksanakan di SMA YP UNJ Rawamangun Jakarta pada semester I untuk siswa kelas sepuluh (XI) tahun ajaran 2006-2007.

\section{Metode dan Desain Penelitian}

Sesuai dengan permasalahan dan tujuan dari penelitian ini, maka metode yang digunakan adalah metode quasi eksperimen, dengan desain sebagai berikut:

Tabel 2. Rancangan Desain Penelitian

\begin{tabular}{|l|l|l|l|}
\hline Kelompok & Pre test & Perlakuan & Post test \\
\hline Eksperimen & $Y_{1}$ & $X_{1}$ & $Y_{2}$ \\
\hline Kontrol & $Y_{1}$ & $X_{2}$ & $Y_{2}$ \\
\hline
\end{tabular}


Keterangan:

$Y_{1}$ : hasil belajar sebelum proses belajar mengajar

$Y_{2}$ : hasil belajar sesudah proses belajar mengajar

$\mathrm{X}_{1}$ : penggunaan penilaian secara portofolio

$\mathrm{X}_{2}$ : tidak menggunakan penilaian secara portofolio

\section{Teknik Pengambilan Sampel}

1. Populasi Target : seluruh siswa Sekolah Menengah Atas YP UNJ Jakarta

2. Populasi Terjangkau: siswa kelas $X I$ SMA YP UNJ Jakarta tahun ajaran 2006-2007 sebanyak 40 siswa

3. Sampel: dari seluruh siswa kelas XI dipilih dua kelas sebagai kelas sampel secara acak, dan selanjutnya kelas tersebut diberikan pelakuan yang berbeda yaitu:

a. Kelompok A belajar fisika dengan menggunakan penilaian secara portofolio

b. Kelompok B belajar fisika tanpa menggunakan penilaian secara portofolio

\section{E. Teknik Pengumpulan Data}

Cara mendapatkan data mengenai hasil belajar siswa dari kelas sampel yang diteliti, diperoleh dari tes hasil belajar fisika yang berupa soal pilihan ganda dan uraian.

1. Variabel yang diteliti

Variabel terikat: hasil belajar siswa dalam pembelajaran fisika

Variabel bebas: penilaian secara portofolio

2. Sumber data

Sumber data adalah sampel yang terdiri dari:

Kelas A: kelas XI SMA dengan jumlah siswa 40 orang

Kelas B: kelas XI SMA dengan jumlah siswa 40 orang

3. Rancangan Penelitian

Di dalam rancangan penelitian ini, perlakuan yang diberikan terhadap kelompok sampel yang diteliti adalah sebagai berikut: a. Pembentukan kelas penelitian dengan cara penempatan acak (random assignment).

b. Pemberian tes awal (pre test) terhadap kelas sampel untuk mengetahui kemampuan siswa.

c. Kelas A belajar fisika dengan menggunakan penilaian secara portofolio

d. Kelas B belajar fisika tanpa menggunakan penilaian secara portofolio

e. Setelah seluruh pokok bahasan selesai, diadakan tes hasil belajar akhir (post test) terhadap dua kelas penelitian.

f. Hasil tes diuji dengan menggunakan uji-t (sampel bebas) untuk mencari perbedaan skor rata-rata antara kelas $\mathrm{A}$ dan B. Kelas manakah yang mempunyai skor rata-rata lebih tinggi.

4. Instrumen Penelitian

Instumen yang digunakan pada penelitian ini adalah bentuk soal pilihan ganda untuk pokok bahasan Suhu dan Kalor, yang terdiri dari 30 soal. Soal-soal dibuat untuk mengukur ranah kognitif pada aspek pemahaman, penerapan, analisis dan sintesis.

5. Hasil Uji Coba Instumen

Pengujian validitas tes pada penelitian ini adalah dengan menggunakan validitas isi (content validity). Untuk menghitung validitas tiap butir soal sebagai instrument penelitian digunakan teknik korelasi biserial titik (point biserial correlation) atau $r_{p b i s}$ yaitu:

$$
r_{p b i s}=\frac{M_{p}-M_{t}}{S_{t}} \sqrt{\frac{p}{q}}
$$

Keterangan:

$$
\begin{aligned}
& \mathrm{R}_{\mathrm{pbis}} \quad \text { : koefisien korelasi point biserial } \\
& \mathrm{M}_{\mathrm{p}} \quad \text { : Mean dari subyek-subyek yang } \\
& \text { menjawab benar item yang dicari } \\
& \text { korelasinya dengan tes } \\
& M_{t} \quad \text { : Mean skor total (rata-rata skor dari } \\
& \text { seluruh pengikut tes) } \\
& \mathrm{S}_{\mathrm{t}} \quad \text { : Standar deviasi skor total } \\
& \mathrm{p} \quad \text { : Proporsi subyek yang menjawab }
\end{aligned}
$$


benar

q : : Proporsi subyek yang menjawab salah

$q=1-p$

Selanjutnya dihitung dengan uji $-\mathrm{t}$ dengan rumus:

$$
t_{\text {hitung }}=\frac{r \sqrt{n-2}}{\sqrt{1-r^{2}}}
$$

Keterangan:

$\mathrm{t}_{\text {hitung }}$ : nilai $\mathrm{t}$ hitung

$r \quad$ : koefisien korelasi hsil $r_{\text {hitung }}$

$\mathrm{n} \quad$ : jumlah responden (pengikut tes)

Distribusi (tabel t) untuk á $=0,05$ dan derajat kebebasan ( $d k=n-2)$, maka untuk $t_{\text {hitung }}$ lebih besar dari $t_{\text {tabel }}$ berarti valid, dan untuk $\mathrm{t}_{\text {hitung }}$ lebih kecil dari $\mathrm{t}_{\text {tabel }}$ berarti tidak valid.

Untuk menguji reliabilitas soal, dihitung menggunakan rumus KR-20 sebagai berikut:

$$
r_{11}=\left(\frac{k}{k-1}\right)\left(\frac{s^{2}-\sum p q}{s^{2}}\right)
$$

Keterangan:

$r_{11}$ : koefisien reliabilitasi internal seluruh item

p : proporsi subyek yang menjawab item benar

q : proporsi subyek yang menjawab item salah

$\sum p q$ : jumlah hasil perkalian $\mathrm{p}$ dan $\mathrm{q}$

$\mathrm{k}$ : banyaknya item

$\mathrm{s}^{2} \quad$ : standar deviasi dari tes

Selanjutnya untuk mengetahui instrument penelitian reliable atau tidak maka harga $r_{11}$ dari KR-20 dibandingkan dengan $r_{\text {tabel }}$ dengan á = 0,05 dan derajat kebebasan $\mathrm{dk}=\mathrm{n}-2$. Untuk $\mathrm{r}_{11}$ lebih besar dari $r_{\text {tabel }}$ berarti reliable, sebaliknya untuk $r_{11}$ lebih kecil dari $r_{\text {tabel }}$ berarti tidak reliabel.

Ini digunakan untuk mengetahui apakah instrumen bersifat tetap dalam setiap penelitian.

\section{F. Teknik Analisis Data}

Data yang diperoleh dari penelitian dalam bentuk angka-angka sehingga sifat-sifat yang penting dan bentuk penyebaran dari data tersebut dapat dengan mudah diketahui dan diinterpretasikan.

Untuk mengetahui apakah terdapat perbedaan rata-rata hasil belajar fisika siswa antara siswa yang belajar dengan menggunakan penilaian secara portofolio dengan siswa yang belajar tanpa menggunakan penilaian secara portofolio, maka dapat dirumuskan hipotesis statistiknya yaitu:

$$
\begin{aligned}
& H_{o}=\mu_{A} \leq \mu_{B} \\
& H_{1}=\mu_{A} \succ \mu_{B}
\end{aligned}
$$

Keterangan :

$\mu_{\mathrm{A}}$ : mean hasil belajar fisika siswa yang belajar dengan menggunakan penilaian secara portofolio

$\mu_{B}$ : mean hasil belajar fisika siswa yang belajar tanpa menggunakan penilaian secara portofolio

$H_{\circ}$ : hipotesis nol, yaitu mean hasil belajar fisika siswa yang menggunakan penilaian secara portofolio kurang dari atau sama dengan mean hasil belajar fisika siswa yang tidak menggunakan penilaian secara portofolio

$\mathrm{H}_{1}$ : hipotesis penelitian, yaitu mean hasil belajar fisika siswa yang menggunakan penilaian secara portofolio lebih tinggi dari pada siswa mean hasil belajar fisika siswa yang tidak menggunakan penilaian secara portofolio.

Sebelum dilakukan penelitian pada kedua kelompok sampel terlebih dulu diberi pre test untuk menguji homogenitas yaitu untuk mengetahui tingkat kemampuan awal, maka digunakan uji F. Kemudian kedua sampel diberi post test (intrumen penelitian) untuk menguji normalitas dengan menggunakan uji liliefors.

Rumus uji $F: F_{n}=\frac{\sigma_{A}^{2}}{\sigma_{B}^{2}}$

$\sigma_{A}^{2}$ : variansi populasi siswa yang menggunakan penilaian secara 
portofolio (varians terbesar)

$\sigma_{B}^{2}$ :variansi populasi siswa yang tidak menggunakan penilaian secara portofolio (varians terkecil)

Setelah kedua uji persyaratan terpenuhi maka pengujian dilanjutkan dengan uji-t untuk sampel bebas dengan taraf signifikansi $5 \%(a ́=0,05)$ dan derajat kebebasan $d k=n_{A}+n_{B}-2$.

$$
t_{\text {hitung }}=\frac{\bar{X}_{A}-\bar{X}_{B}}{S \sqrt{\left(\frac{1}{n_{A}}+\frac{1}{n_{B}}\right)}}
$$

Keterangan :

$\bar{X}_{A}: \begin{aligned} & \text { skor rata-rata hasil belajar siswa yang } \\ & \text { menggunakan penilaian secara }\end{aligned}$
portofolio
$\bar{X}_{B}: \begin{aligned} & \text { skor rata-rata hasil belajar siswa yang } \\ & \text { tidak menggunakan penilaian secara } \\ & \text { portofolio }\end{aligned}$

S : simpangan baku untuk kelas eksperimen dan kelas kontrol

$\mathrm{n}_{\mathrm{A}} \quad$ : jumlah siswa kelompok $\mathrm{A}$

$n_{B} \quad$ : jumlah siswa kelompok $B$

$t \quad$ : nilai t untuk sampel bebas

\section{G. Langkah Penelitian}

1) Menentukan tujuan pembelajaran yang hendak dicapai

2) Membuat Rancangan Pembelajaran

3) Membuat soal-soal pre test dan post test

4) Membuat lembar penilaian portofolio

5) Mengadakan pre test pada kelas eksperimen dan kelas kontrol untuk mengukur tingkat kemampuan siswa

6) Melaksanakan penelitian terhadap kelas eksperimen untuk mengetahui pengaruh penggunaan penilaian secara portofolio terhadap hasil belajar fisika siswa

7) Mengadakan post test pada kedua kelas sampel

\section{HASIL PENELITIAN}

Sebelum penelitian,dilakukan tes terhadap anak kelas XI IPA di SMA YP UNJ Jakarta sebanyak 30 siswa, untuk menguji tingkat validitas dan reliabilitas soal, taraf kesukaran dan daya beda soal. Dari hasil uji validitas ada 7 soal yang drop dan dari daya beda soal ada 7 soal yang harus direvisi, ketujuh soal tersebut adalah soal yang sama. Sehingga untuk selanjutnya pada penelitian digunakan 23 soal untuk pre test dan post test. Dari hasil uji reliabilitas dengan menggunakan rumus KR-20 diperoleh nilai $r_{11}=0,866$, sementara nilai $r_{\text {tabel }}=0,374$ untuk taraf signifikansi $\alpha=0,05$ dan derajat kebebasan $\mathrm{dk}=\mathrm{n}-2=$ $30-2=28$. Sehingga $r_{11}$ lebih besar dari pada $r_{\text {tabel }}$ berarti soal bersifat reliable.

Penelitian ini menggunakan hasil belajar fisika sebagai variabel terikat dan penilaian secara portofolio sebagai variabel bebas. Data penelitian ini diperoleh dari hasil tes sumatif siswa kelas eksperimen yaitu kelas yang dipenilaian menggunakan portofolio dan kelas kontrol yaitu kelas yang tidak dipenilaian secara portofolio.

\section{A. Deskripsi Data}

Data yang diambil pada penelitian ini adalah data hasil belajar Fisika siswa yang berupa kemampuan kognitif pada kelompok siswa yang diajar dengan menggunakan penilaian portofolio (kelas eksperimen) dan yang diajar tanpa menggunakan penilaian secara portofolio (kelas kontrol). Data selengkapnya mengenai hasil belajar siswa tersebut akan diuraikan sebagai berikut :

\section{Hasil Belajar Siswa Kelas Eksperimen}

Sebelum diberi perlakuan, dari 30 siswa yang diamati, diperoleh sebaran data sebagai berikut: nilai tertinggi 6,52 dan terendah 2,61 dengan rata-rata 4,60 . Sedangkan setelah perlakuan nilai tertinggi meningkat menjadi 8,26 dan terendah 3.91 dengan rata-rata 6,46 .

Distribusi frekuensi dan diagram batang hasil belajar siswa kelas eksperimen adalah sebagai berikut: 


\section{Hasil Belajar Siswa Kelas Kontrol}

Untuk kelas kontrol (penilaian tanpa menggunakan portofolio), dari 30 siswa yang diamati, diperoleh sebaran data sebelum perlakuan sebagai berikut : nilai tertinggi 6,52 dan terendah 2,61 dengan rata-rata 4,55 . Sedangkan nilai setelah perlakuan adalah : nilai tertinggi 7.83 dan terendah 3.84 dengan rata-rata 5,77 .

Distribusi frekuensi dan diagram batang hasil belajar siswa kelas kontrol dapat dilihat dalam tabel dan gambar berikut ini :

Tabel 3. Distribusi frekuensi hasil belajar fisika siswa kelas eksperimen

\begin{tabular}{|l|l|l|l|l|l|l|}
\hline No. & Interval & \multicolumn{2}{|l|}{ Batas Nyata } & $\begin{array}{l}\text { Titik } \\
\text { tengah }\end{array}$ & $\begin{array}{l}\text { Frek. } \\
\text { Absolut }\end{array}$ & $\begin{array}{l}\text { Frek. } \\
\text { Relatif(\%) }\end{array}$ \\
\hline & & Bawah & Atas & & & \\
\hline 1 & $3.90-4.64$ & 3.895 & 4.645 & 4.27 & 3 & 10 \\
\hline 2 & $4.65-5.39$ & 4.645 & 5.395 & 5.02 & 2 & 6.666667 \\
\hline 3 & $5.40-6.14$ & 5.395 & 6.145 & 5.77 & 7 & 23.33333 \\
\hline 4 & $6.15-6.89$ & 6.145 & 6.895 & 6.52 & 6 & 20 \\
\hline 5 & $6.90-7.64$ & 6.895 & 7.645 & 7.27 & 5 & 16.66667 \\
\hline 6 & $7.65-8.39$ & 7.645 & 8.395 & 8.02 & 7 & 23.33333 \\
\hline
\end{tabular}

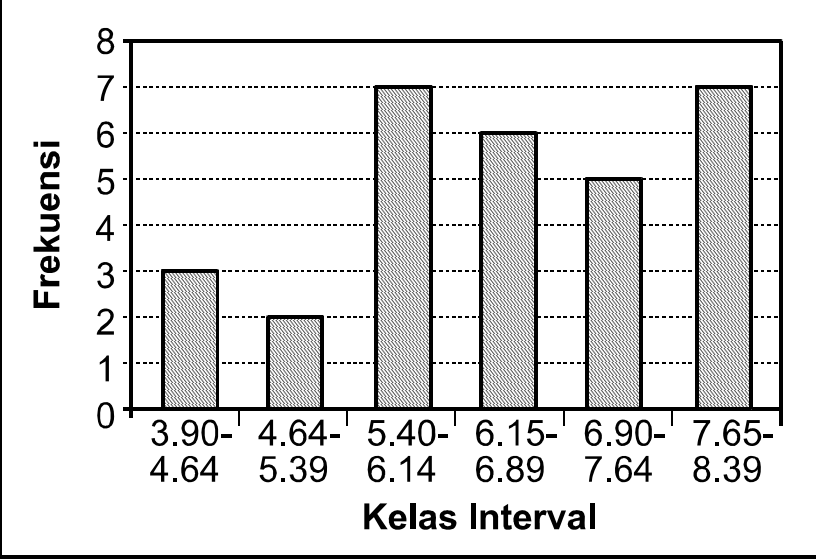

Gambar 1.

Diagram batang frekuensi hasil belajar siswa kelas eksperimen

\section{B. Pengujian Persyaratan Analisis}

Sebelum dilakukan pengujian hipotesis, terlebih dahulu dilakukan persyaratan analisis yang terdiri dari:

1. Uji Normalitas

Uji normalitas bertujuan untuk mengetahui apakah sampel hasil belajar terdistribusi normal atau tidak. Pengujian ini dilakukan dengan menggunakan uji
Liliefors terhadap hasil belajar fisika siswa yang dipenilaian menggunakan portofolio dan dipenilaian tanpa menggunakan portofolio. Uji ini didasarkan pada selisih maksimum antara $F(Z)$ distribusi kumulatif dengan $S(Z)$ distribusi kumulatif sampel.

Hasil uji normalitas selengkapnya untuk kedua kelompok sebelum dan sesudah perlakuan disajikan sebagai berikut: 


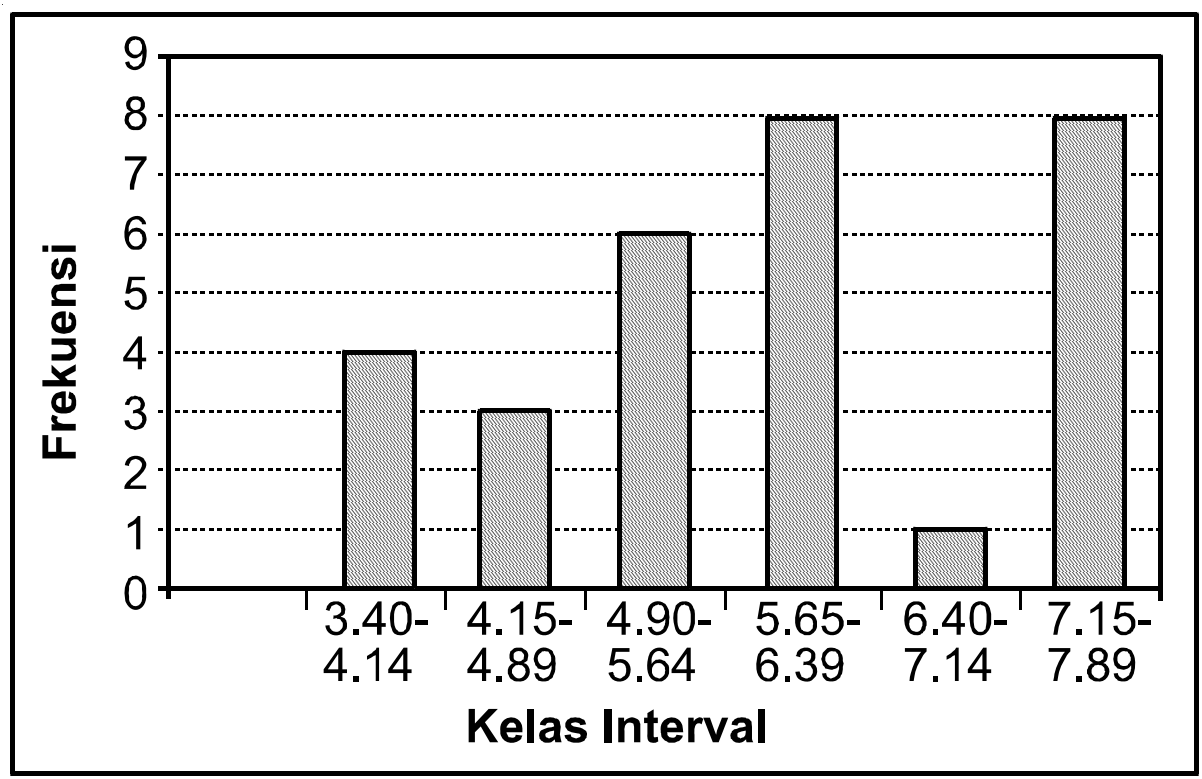

Diagram batang frekuensi hasil belajar fisika kelas kontrol

Berdasarkan data pada table di atas, untuk kedua kelas baik kelas eksperimen maupun kelas kontrol didapat bahwa sebelum dan sesudah perlakuan nilai $L_{0}<L_{\text {tabel }}$ sehingga berdasarkan pada kriteria pengujian dapat disimpulkan bahwa data hasil belajar fisika siswa terdistribusi normal.

2. Uji Homogenitas

Pengujian ini bertujuan untuk mengetahui apakah sampel hasil belajar fisika siswa berasal dari kelas yang homogen atau tidak. Pengujian ini menggunakan uji $\mathrm{F}$ yakni dengan menggunakan nilai perbandingan antara varians terbesar dengan varians terkecil. Kemudian nilai ini dibandingkan dengan nilai $F_{\text {tabel }}$ untuk taraf signifikansi á $=0,05$ dengan derajat kebebasan dk penyebut $=\mathrm{n}-1$ dan dk pembilang $=\mathrm{n}-1$.

Hasil dari uji homogenitas sebelum perlakuan diperoleh $\mathrm{F}$ hitung sebesar 1.754 , sedangkan $\mathrm{F}_{\text {table }}=1.85$.

Berdasarkan data diatas, didapat bahwa nilai $F_{\text {hitung }}<F_{\text {tabel' }}$, sehingga berdasarkan kriteria pengujian dapat disimpulkan bahwa data hasil belajar fisika kedua kelas sampel berasal dari kelas yang homogen.

Tabe1 5. Data hasil uji normalitas kedua kelompok siswa sebelum dan sesudah perlakuan

\begin{tabular}{|l|l|l|l|l|l|}
\hline No. & Kelompok & $\begin{array}{l}\text { Jumlah } \\
\text { Siswa }\end{array}$ & waktu & $\mathrm{L}_{0}$ & $\mathrm{~L}_{\text {tabel }}$ \\
\hline 1. & Eksperimen & 30 & $\begin{array}{l}\text { Sebelum } \\
\text { perlakuan }\end{array}$ & 0,1547 & 0.161 \\
\cline { 3 - 6 } & & $\begin{array}{l}\text { Sesudah } \\
\text { perlakuan }\end{array}$ & 0,084 & 0.161 \\
\hline 2. & Kontrol & 30 & $\begin{array}{l}\text { Sebelum } \\
\text { perlakuan }\end{array}$ & 0,1423 & 0.161 \\
\cline { 4 - 6 } & & $\begin{array}{l}\text { Sesudah } \\
\text { perlakuan }\end{array}$ & 0.109 & 0.161 \\
\hline
\end{tabular}




\section{Pengujian Hipotesis}

Setelah data memenuhi persyaratan analisis, kemudian dilanjutkan dengan pengujian hipotesis menggunakan perhitungan statistic Uji - t. Dari data penelitian didapat bahwa rata-rata hasil belajar kelas eksperimen (kelas yang menggunakan penilaian secara portofolio) sebesar 6.46 dengan simpangan baku sebesar 1.269 , sedangkan rata-rata hasil belajar kelas kontrol (kelas yang tidak menggunakan penilaian secara portofolio) sebesar 5.77 dengan simpangan baku 1.371.

Dari hasil perhitungan uji- t diperoleh nilai $t_{\text {hitung }}$ sebesar 2.0245. Uji-t yang dilakukan adalah uji pihak kanan dengan taraf signifikansi á $=0.05$ dan derajat kebebasan $d k=n_{A}+n_{B}-2=30+30-2=$ 58. Untuk batasan -batasan tersebut, dari table kritis uji-t diperoleh nilai $t_{\text {tabel }}$ sebesar 2.000 .

Dari data hasil perhitungan di atas (selengkapnya baca dilampiran uji-t setelah perlakuan), didapat bahwa nilai $t_{\text {hitung }}>t_{\text {tabel }}$. Maka $\mathrm{H}_{0}$ ditolak dan $\mathrm{H}_{1}$ diterima. Hal ini berarti terdapat perbedaan hasil belajar antara kelompok kelas yang dipenilaian menggunakan portofolio (kelas eksperimen) dengan kelas yang tidak dipenilaian menggunakan portofolio (kelas kontrol), dimana hasil belajar kelas eksperimen lebih tinggi daripada kelas kontrol.

\section{Pembahasan HasilPenelitian}

Berdasarkan hasil pengujian yang telah dilakukan, maka terdapat peningkatan hasil belajar fisika pada kelas yang dipenilaian menggunakan portofolio. Hal ini menunjukkan bahwa penilaian secara portofolio memberikan pengaruh yang positif terhadap hasil belajar fisika siswa.

Adanya pengaruh penggunaan penilaian secara portofolio terhadap hasil belajar fisika siswa sesuai dengan fungsi penggunaan penilaian secara portofolio yakni untuk melihat perkembangan tingkat kemajuan belajar siswa. Penilaian secara portofolio dilakukan untuk melihat perkembangan tingkat penguasaan siswa terhadap tiap indikator pencapaian hasil belajar. Adanya penugasan untuk membuat makalah dan mempresentasikannya diakhir pembelajaran, membuat siswa berusaha mencari pengetahuan lebih banyak diluar jam sekolah yang berkaitan dengan materi yang sedang dibahas. Penilaian terhadap afektif dan psikomotorik siswa pun memicu mereka untuk lebih aktif dalam setiap kegiatan belajar mengajar. Selain itu siswa juga diberi kesempatan untuk menilai hasil kerjanya sendiri, dengan tujuan agar siswa mengetahui hasil kerja terbaik mereka dan dimana kekurangan mereka, sehingga diharapkan siswa akan memperbaiki kekurangan tersebut.

\section{KESIMPULAN, IMPLIKASI DAN SARAN}

\section{A. Kesimpulan}

Berdasarkan hasil pengolahan data hasil belajar siswa, terdapat perbedaan hasil belajar fisika siswa antara yang dinilai menggunakan portofolio (nilai rata-rata sebesar 6.46) dengan yang tidak menggunakan portofolio (nilai rta-rata sebesar 5.77). Hal ini terlihat dari perhitungan uji - $\mathrm{t}$ yang diperoleh nilai $t_{\text {hitung }}$ sebesar 2.0245 dan $t_{\text {tabel }}$ sebesar 2.000. Padahal sebelum dilakukan penelitian nilai rata-rata hasil belajar fisika kedua kelas hampir sama yakni 4.60 untuk kelas eksperimen dan 4.55 untuk kelas kontrol. Dari data tersebut, dapat dilihat bahwa peningkatan hasil belajar siswa kelas eksperimen lebih tinggi daripada peningkatan hasil belajar kelas kontrol.

Dari keterangan di atas secara impisit dapat disimpulkan bahwa dengan adanya penggunaan penilaian secara portofolio memberikan pengaruh yang positif terhadap hasil belajar fisika yakni berupa peningkatan hasil belajar fisika siwa. Peningkatan hasil belajar siswa ini dikarenakan pada penilaian portofolio siswa diberi tugas untuk tiap indikator dan 
setiap indikator yang belum dikerjakan dengan baik siswa akan terus memperbaikinya hingga penguasaan terhadap indikator tersebut tercapai.

\section{B. Implikasi}

Hasil penelitian ini diharapkan dapat menjadi pertimbangan bagi guru atau calon guru, khususnya bidang studi Fisika dalam menggunakan penilaian secara portofolio kepada siswa sebagai alternative cara untuk meningkatkan hasil belajar fisika siswa dan mengoptimalkan kemampuan siswa dalam belajar.

\section{Saran}

Berdasarkan hasil penelitian, penilaian menggunakan portofolio dapat meningkatkan hasil belajar siswa, untuk itu diharapkan agar guru atau calon guru fisika untuk menggunakan portofolio dalam mengpenilaian siswa. Namun demikian, penggunaaan penilaian secara portofolio mempunyai kelemahan, khususnya pada siswa yang belum mengerti mengenai portofolio. Ada beberapa siswa yang cenderung malas untuk memperbaiki dan melengkapi tugas-tugasnya.

Penilaian secara portofolio ini lebih baik dilakukan untuk mengpenilaian siswa secara individu, sehingga terlihat tingkat kemajuan siswa dalam pembelajaran secara objektif, detail dan lengkap. Oleh karena itu, dibutuhkan kerja ekstra dari guru dalam melakukan penilaian.

Penelitian ini merupakan langkah awal untuk mengembangkan model penilaian yang lebih baik lagi, khususnya untuk mata pelajaran fisika. Karena dalam ilmu fisika terdapat banyak materi yang membutuhkan aplikasi ilmu pengetahuan, yang diharapkan siswa dapat melakukan unjuk kerja dan praktik, daripada sekedar mengetahui konsep-konsep fisika saja. Maka alangkah baiknya kalau secara bertahap guru mulai menerapkan model penilaian secara portofolio, artinya guru menilai siswa berdasarkan ketiga aspek yaitu kognitif, afektif dan psikomotorik, sehingga siswa memperoleh pembelajaran yang bermakna dan penilaian yang otentik.

Karena keterbatasan studi yang tejadi dalam penelitian ini, disarankan pula untuk melaksanakan penelitian lebih lanjut, guna mengetahui apakah penilaian secara portofolio ini dapat berpengaruh terhadap peningkatan hasil belajar fisika siswa untuk materi pelajaran yang lain ataupun dengan sampel yang dapat mewakili berbagai sekolah dengan kondisi yang berbeda.

\section{DAFTAR PUSTAKA}

Yamin,Martinis. 2004. Strategi pembelajaran Berbasis Kompetensi. Pamulang:Gaung Persada press.

Dwi Asworo,Yuliana. 2005. Skripsi: Analisis Penggunaan Penilaian Unjuk Kerja (Performances Assesment) Pada Pembelajaran Kimia di SMA. Universitas Negeri Jakarta.

Supriyati,Yetti. 2004. Makalah: Sistem Penilaian Portofolio Dalam Pembelajaran Matematika dan IImu Pengetahuan Alam.

Imran, Ali. 1996. Belajar dan Pembelajaran. Jakarta: Pustaka Jaya.

Sudjana, Nana. 1997. Cara Belajar Siswa Aktif dalam Proses Belajar Mengajar. Bandung: Sinar Baru.

Miarso, Yusufhadi. 1994. Definisi Teknologi Pendidikan. Jakarta: Rajagrafindo Persada.

Kertiasa, Nyoman.1997. Fisika untuk SMU kelas I. Jakarta: Balai Pustaka.

Druxes, Herbert. 1983. Kependium Didaktik Fisika. Terjemahan Soepomo. Bandung: CV Remaja Karya

Kanginan, Marthen. 2002. Fisika untuk SMA kelas $X$. Jakarta: Erlangga.

Suparno, Paul. 1997. Filsafat Konstruktifisme dalam Pendidikan. Yogyakarta: Kanisius.

S. Kangelosi, James. 1995. Merancang Tes untuk Menilai Prestasi Siswa. Bandung: ITB

Budimansyah, Dasim. 2003. Model Pembelajaran Portofolio. Bandung: PT Genesindo.

Surapranata, Sumarna dan Hatta, Muhammad. 2006. Penilaian Portofolio Implementasi Kurikulum 2004. Bandung: Remaja Rosdakarya Offset. 
Rusoni, Elin. 2001. Portofolio dan Paradigma Baru dalam Penilaian Matematika. www. Depdiknas.go.id

Sudjana, Nana. 1992. Penelitian Hasil Belajar Mengajar. Bandung: Rosdakarya.

Sudjana, Nana. 2001. Penilaian Hasil Proses Belajar Mengajar. Bandung: Rosdakarya.

Sugiyono. 2005. Statistika untuk Penelitian. Bandung: CV Alfabeta. 